\title{
REGIONAL SPECIALISATION AND ECONOMIC CONCENTRATION IN ROMANIA
}

\author{
Olimpia Neagu \\ "Vasile Goldis" Western University of Arad \\ Madalin-Ioan Neagu \\ Technical University of Cluj Napoca
}

(Received April 2016; Accepted May 2016)

\begin{abstract}
The purpose of the paper is to give an overview of the changes in the structure of industries in Romania, specifically on the questions (1) whether the industrial structures become more similar or more different in the Romanian regions and (2) whether the Romanian industries become more concentrated or more dispersed. EUROSTAT regional data on Gross Value Added and employed population for the period of 2000-2013 are used in order to calculate several statistical indices of specialization and concentration (Krugman, Entropy, Hirschman-Herfindahl, Lilien Index and Gini coefficient). By comparing the values of these different measurements, the main finding is that Romanian regions become less specialized, while industries become slightly more concentrated. The speed of structural changes in all Romanian regions registered a noticeable slowdown of the speed of sectoral changes after the economic crisis. Our conclusions provide useful information for the economic policy makers in investment funds allocation or employment measures designing.
\end{abstract}

Key words: specialization, concentration, regional development, Romania JEL Codes: R11, R12, L16, R23

\section{Introduction}

In almost all literature on specialisation and concentration, regional specialisation and geographic concentration of economic activities are analysed in connection or interrelation. Some theories are stating that specialisation and concentration are two faces of the same coin and can evolve together (Aiginger and Rossi-Hansberg, 2006).There are also, some empirical studies, suggesting that they are independent economic processes going to take place at different speeds (Dalum et al., 1998) or in opposite directions when transport costs change (Aiginger and Rossi-Hansberg, 2006).

The aim of the paper is to investigate whether the Romanian regional economic structures are converging or diverging to the national economic structure and whether economic branches are more concentrated or more dispersed. In this view, we have used different statistical measures for 
regional specialisation and economic concentration, in order to capture various facets of these phenomena.

The paper is organised as follows: after a short literature review on regional specialisation and economic concentration, the methodology and data are explained. In the third section, the results are exposed. The final section is dedicated to Discussion and conclusions.

\section{A brief literature review on regional specialisation and economic concentration}

The issues of regional specialisation and economic concentration are explored by scientists in the context of analyzing the process of economic convergence and its effects at European or world level (Molle, 1996; Hallet, 2002; Cornett, 2002; Marelli, 2007; Ezcurra et.al, 2006). For instance, Molle (1996) and Hallet (2002) conducted studies on regional convergence in the European Union, based on NUTS 1 and NUTS 2 data. Molle identified the existence of high convergence of regions' production structure and a high degree of specialisation of periphery regions and Hallet found a decrease of specialisation correlated with a movement toward the European average of regions' production structure. Cornett (2002) highlighted the characteristics of interregional specialisation based on intra-industry and inter-state trade. Ezcurra et.al (2006) emphasizes a decreasing tendency of regional specialisation for the examined period (1977-1999).

The regional specialisation and economic concentration in Romania was explored by several authors. For instance, Traistaru et.al (2002, 2003), Traistaru and Iara (2002), Longhi et al. (2004) researched these issues in a group of other European accession countries at that time (Bulgaria, Slovenia, Hungary and Estonia). The authors explained the impact of European economic integration on patterns of regional specialisation and concluded that the regional specialisation is negatively correlated with regional GDP per capita and unemployment rate. The changes in regional specialisation patterns and its impact on economic growth were also analyzed by Traistaru, Iara, Pauna (2002).

The effects of transition, structural changes and privatisation on regional specialisation were analyzed in several studies conducted by Romanian authors, as well (Mitrut and Constatin, 2006; Andrei et al. 2008; Andrei et al.2009; Goschin et al. 2008, 2009).

A set of possibilities to measure regional specialisation and economic or geographic concentration are masterfully exposed in some working papers of Goschin et.al (2008, 2009), such as: Krugman, Hirschman-Herfindahl, Lilien and Gini Index. 


\section{Methodology and data}

Specialisation is defined as distribution of the shares of industries (or economic branches) in a specific country or region (Aiginger, 1999). We call highly specialised a country/ region with a small number of branches responsible for a large share of production (Gross Value Added) or employment. If the production structures disperse (shares become more equal across economic branches) we speak about diversification or dispersion. Economic or geographic concentration is the distribution of the shares of regions in an individual economic branch or industry (Aiginger, 1999, Traistaru, 1999). An economic branch is concentrated if a large part of production is carried out in few regions.

For the purpose of the paper we will use the following measures for industries concentration and regional specialisation: Krugman, Entropy, Herfindahl Indexes, Gini Coefficient and Lilien Index.

The Krugman Index (Krugman, 1991) for measuring concentration of industries or specialisation of regions is:

$$
K_{j}^{c}=\sum_{i=1}^{n}\left|s_{i j}^{c}-s_{i}\right| \quad \text { (1) } \quad K_{i}^{s}=\sum_{j=1}^{m}\left|s_{i j}^{s}-s_{j}\right|
$$

where: $s_{i}=\frac{X_{i}}{X}, s_{j}=\frac{X_{j}}{X}, s_{i j}^{c}=\frac{x_{i j}}{X_{i}}, s_{i j}^{s}=\frac{x_{i j}}{X_{j}}$.

$K_{j}^{c}$ is the Krugman Index for concentration of branch $j, K_{i}^{s}$ is the Krugman Index for specialization of region $\mathrm{i}, s_{i j}^{c}$ is the share of branch $\mathrm{j}$ in the region $\mathrm{i}, s_{i j}^{s}$ is the share of region $\mathrm{i}$ in the branch $\mathrm{j}, x_{i j}$ is the Gross Value Added or employment in region $\mathrm{i}$ and branch $\mathrm{j}, X_{i}$ is the total Gross Added Value or employment of the region $\mathrm{i}, X_{j}$ is the total Gross Added Value or employment for the branch $\mathrm{j}$ and $\mathrm{X}$ stands for the total national Gross Value Added or employment.

The value of Krugman Index is used to compare branches of regions with the national economy or to compare two regions. Its values are between 0 (identical territorial/sectoral structures) and 2 (totally different structures).

The generalised entropy measure (GE) is given by the formula:

$G E(\alpha)=\frac{1}{\alpha(\alpha-1)}\left[\frac{1}{n} \sum_{i=1}^{n}\left(\frac{y_{i}}{\bar{y}}\right)^{\alpha}-1\right]$

where: $y_{i}$ is the variable of the unit $i$ and $\bar{y}$ is the average of it. 
The values of GE measures vary between 0 and $\infty$, with zero representing an equal distribution and higher value representing higher level of inequality. The parameter $\alpha$ in the GE represents the weight given to distances between variables at different parts of variable distribution, and can take any real value. The commonest values of $\alpha$ used are 0,1 and 2 .

For $\alpha=1$ the formula becomes:

$G E(\alpha)=\frac{1}{n} \sum_{i=1}^{n} \frac{y_{i}}{\bar{y}} \ln \frac{y_{i}}{\bar{y}}$

and for $\alpha=0: \quad \mathrm{GE}(0)=-\frac{1}{n} \sum_{i=1}^{n} \ln \frac{y_{i}}{\bar{y}}$

The entropy index (E) commonly known as the Shannon Entropy index is used in the research of income distribution (Cowell, 1980, 1995 and 2000) and applied also in measurement of specialisation (Attaran and Zwick, 1987; Smith and Gibson, 1988; Aiginger and Davies, 2004; Aiginger and Pfaffermayr, 2004).

We will use the following formula for entropy of specialisation and concentration:

$E^{s}=-\sum_{i=1}^{n} s_{i j}^{s} \ln s_{i j}^{s}$ for specialisation (6) and

$E^{c}=-\sum_{j=1}^{m} s_{i j}^{c} \ln s_{i j}^{c}$ for concentration (7)

$0 \leq \mathrm{E} \leq 1$,

where: $s_{i j}^{c}=\frac{x_{i j}}{X_{i}}$ and $s_{i j}^{s}=\frac{x_{i j}}{X_{j}}$.

The entropy index increases with a decreasing specialisation, the lower bound (0) gives absolute specialisation and the upper bound ( $\ln 1)$ complete diversification, with each economic branch having the same Gross Value Added or employment share.

One of the most commonly used indicators for concentration/specialisation is the Hirschman- Herfindahl index (Herfindahl, 1950; Hirschman, 1964) for instance, in industrial economics (Scherer, 1990) to measure market concentration and economic diversity (Tauer, 1992) and for macroeconomic specialisation analyses (Sapir, 1996; Davis, 1998; Storper et al., 2002; Aiginger and Pfaffermayr, 2004; Beine and Coulombe, 2007).

$$
H_{j}^{c}=\sum_{i=1}^{n}\left(s_{i j}^{c}\right)^{2} \text { for concentration }
$$




$$
H_{i}^{c}=\sum_{j=1}^{m}\left(s_{i j}^{c}\right)^{2} \text { for specialisation }
$$

where:

$$
s_{i j}^{c}=\frac{X_{i j}}{\sum_{i=1}^{n} X_{i j}}=\frac{X_{i j}}{X_{j}} \quad s_{i j}^{s}=\frac{X_{i j}}{\sum_{j=1}^{m} X_{i j}}=\frac{X_{i j}}{X_{i}}
$$

$H_{j}^{c}$ is the Herfindahl index for concentration, $H_{i}^{s}$ is the Herfindahl index for specialisation, $s_{i j}^{c}$ is the share of region $\mathrm{i}$ in the national value of branch $\mathrm{j}, s_{i j}^{s}$ is the share of branch $\mathrm{j}$ in the total value of region $\mathrm{i}, X_{i j}^{c}$ and $X_{i j}^{s}$ is Gross Value Added or employment of the branch $\mathrm{j}$ in region $\mathrm{i}, X_{i}$ is the Gross Value Added or employment of region $\mathrm{i}, X_{j}$ is the Gross Value Added or employment of branch $\mathrm{j}$. The value of Herfindahl index is increasing with the degree of concentration/specialisation. It has values between 0 and 1.The highest value of 1 is reached when the branch $\mathrm{j}$ is concentrated in one region or the region $\mathrm{i}$ is specialised in one branch. The lowest level of $1 / \mathrm{m}$ corresponds to the situation when all branches have equal shares in region 1 or the level of $1 / \mathrm{n}$ when all regions have equal shares in branch $\mathrm{j}$.

For calculating the Gini coefficient we will use the following formula:

$G^{s}=\frac{2}{n^{2} \overline{X_{i}}} \sum_{i=1}^{n}\left(\left(i-\frac{n+1}{2}\right) x_{i j}\right) \quad(10)$, where: $0 \leq \mathrm{G} \leq 1, \overline{X_{i}}=\frac{1}{n} \sum_{i=1}^{n} x_{i j}, i=$ number of regions

$$
G^{c}=\frac{2}{m^{2} \overline{X_{j}}} \sum_{j=1}^{m}\left(\left(j-\frac{m+1}{2}\right) x_{i j}\right) \quad \text { (11), where: } \quad 0 \leq \mathrm{G} \leq 1, \quad \overline{X_{j}}=\frac{1}{m} \sum_{j=1}^{m} x_{i j},
$$

$j=$ number of economic branches.

A higher value of Gini coefficient shows a greater specialisation or concentration.

The Gini coefficient is commonly used in the convergence literature and to highlight inequalities in several economical indicators (GDP per capita, employment, unemployment) between European regions (see for instance: Simionescu, 2014; Neagu, 2013, 2015).

The Lilien Index reflects the speed of sectoral reallocations in the economy as the main factor of specialisation trend (Lilien, 1982).

For the region i, the Lilien Index is calculated as follows: 
$L_{i}^{s}=\sqrt{\sum_{j=1}^{m} \frac{X_{i j}}{X_{i}}\left(\Delta \log X_{i j}-\Delta \log X_{i}\right)^{2}}$

where: $\frac{X_{i j}}{X_{i}}$ is the share of employment in branch $\mathrm{j}$ in region $\mathrm{i}, X_{i j}$ is employment in branch $\mathrm{j}$ in region $\mathrm{i}, X_{i}$ is the total employment in the region $\mathrm{i}, \Delta$ is the first difference operator.

The Lilien Index is used to measure speed of structural changes; a higher value of this indicator suggests a faster structural change and bigger reallocations of employment between branches. It also indicates the flexibility of an economy and its adaptation capacity to the changes in aggregate demand.

We have used data series from EUROSTAT regarding Gross Added Value at current prices and employment (thousand people) for 2000-2013. The values of indexes were calculated using the wessa.net free statistical software and Microsoft Excel functions.

\section{Main findings}

We calculated the above indexes for Gross Added Value data and employment data. The results are displayed in Tables 1, 2 and 3, and Figure 1 (a,b,c,d).

Table 1.a. Specialization of Romanian regions based on Gross Value Added data

\begin{tabular}{|l|c|c|c|c|c|c|c|c|}
\cline { 2 - 9 } \multicolumn{1}{c|}{} & \multicolumn{4}{c|}{ Krugman Index } & \multicolumn{4}{c|}{ Entropy Index } \\
\hline Year/Region & $\mathbf{2 0 0 0}$ & $\mathbf{2 0 0 5}$ & $\mathbf{2 0 0 9}$ & $\mathbf{2 0 1 3}$ & $\mathbf{2 0 0 0}$ & $\mathbf{2 0 0 5}$ & $\mathbf{2 0 0 9}$ & $\mathbf{2 0 1 3}$ \\
\hline North-West & 0,1249124 & 0,1090716 & 0,105298 & 0,1196743 & 0.863777 & 0.844883 & 0.854097 & 0.879115 \\
\hline Centre & 0,1223769 & 0,1542641 & 0,1449041 & 0,1523639 & 0.840490 & 0.823764 & 0.837662 & 0.850098 \\
\hline North-East & 0,1728475 & 0,2196174 & 0,2289497 & 0,2655621 & 0.863665 & 0.850893 & 0.868297 & 0.889787 \\
\hline South-East & 0,1192355 & 0,1027832 & 0,1485867 & 0,2238421 & 0.856185 & 0.840358 & 0.858781 & 0.844553 \\
\hline South - Muntenia & 0,1830883 & 0,2497692 & 0,2224831 & 0,2757647 & 0.829715 & 0.791126 & 0.820084 & 0.813575 \\
\hline Bucharest - Ilfov & 0,3962954 & 0,4483856 & 0,393251 & 0,4698493 & 0.904905 & 0.888486 & 0.896330 & 0.918632 \\
\hline $\begin{array}{l}\text { South-West } \\
\text { Oltenia }\end{array}$ & 0,208036 & 0,2186157 & 0,1834212 & 0,2201284 & 0.841152 & 0.818521 & 0.841699 & 0.839747 \\
\hline West & 0,0767891 & 0,1031592 & 0,1476058 & 0,1945128 & 0.862065 & 0.844182 & 0.844749 & 0.854363 \\
\hline
\end{tabular}

Source: authors' own computations based on EUROSTAT data

As we can notice from Table 1a the Krugman Index increased in almost all regions: in the West region: from 0.07 in 2000 to 0.19 in 2013, in North-East region: from 0.17 in 2000 to 0.26 in 2013, in South-Muntenia: from 0.18 in 2000 to 0.27 in 2013. A lower dynamics was registered in Centre (from 0.12 in 2000 to 0.15 in 2012) and South-West Oltenia (from 0.20 in 2000 to 0.22 in 2013). This index decreased in North-West and is stationary in Bucharest-Ilfov in 2009 compared to 2000, with a highest value in 2013 of 0.46 in this region. 
The low values of this index reflect a similar economic structure with national economy, in all regions. In 2013, the most distant regions from the national structure are North-West, Centre and West.

The value of entropy raised in 2013 compared to 2000 in North-West, Centre, North-East and Bucharest-Ilfov and decreased in 2005 compared to 2000. In other regions such as: South-Muntenia, South-West Oltenia and West the entropy had an inverse evolution: it decreased in 2013 compared to 2000 and increased in 2005 compared to 2000. The period of 2009-2013 was a favorable one for the entropy's increase in all regions except the south of Romania (South-East, South-Muntenia and South-West Oltenia). Increasing values of entropy index always suggest dissolution of specialization of Romanian regions. The southern regions became more specialised (in agriculture, industry, trade and public administration) as those of Northern Romania, in the last four years.

According to Hirschman-Herfindahl Index (Table 1b), the following regions became more specialised between 2000 and 2013: West, South-West Oltenia, and South-Muntenia. In the North-Western and Central regions the situation has changed very little, in the North-East and Bucharest-Ilfov became less specialised. The values of Gini Coefficient (Table 1b) show an increase of regions specialization in 2005 compared to 2000 and a diversification of economic activities in 2013 compared to 2009 in all regions, excepting South-East.

Table 1.b Specialisation of Romanian regions based on Gross Value Added data

\begin{tabular}{|l|c|c|c|c|c|c|c|c|}
\multicolumn{1}{c|}{} & \multicolumn{4}{c}{ Hirschman-Herfindahl Index } & \multicolumn{4}{c|}{ Gini Coeficient } \\
\hline Year/Region & $\mathbf{2 0 0 0}$ & $\mathbf{2 0 0 5}$ & $\mathbf{2 0 0 9}$ & $\mathbf{2 0 1 3}$ & $\mathbf{2 0 0 0}$ & $\mathbf{2 0 0 5}$ & $\mathbf{2 0 0 9}$ & $\mathbf{2 0 1 3}$ \\
\hline North-West & 0.164544 & 0.173311 & 0.169581 & 0.164599 & 0.437507 & 0.459046 & 0.446776 & 0.411463 \\
\hline Centre & 0.184885 & 0.193389 & 0.183522 & 0.187740 & 0.470001 & 0.487613 & 0.469948 & 0.446928 \\
\hline North-East & 0.164035 & 0.164391 & 0.154264 & 0.149418 & 0.436961 & 0.444126 & 0.412385 & 0.391229 \\
\hline South-East & 0.172039 & 0.175989 & 0.161572 & 0.180652 & 0.449458 & 0.464828 & 0.432290 & 0.453927 \\
\hline South - Muntenia & 0.190431 & 0.212162 & 0.192443 & 0.208173 & 0.483864 & 0.525227 & 0.486091 & 0.489643 \\
\hline Bucharest - Ilfov & 0.144721 & 0.152096 & 0.142738 & 0.130125 & 0.350153 & 0.389480 & 0.369059 & 0.312726 \\
\hline $\begin{array}{l}\text { South-West } \\
\text { Oltenia }\end{array}$ & 0.179494 & 0.189929 & 0.171825 & 0.185024 & 0.467878 & 0.490782 & 0.460598 & 0.462632 \\
\hline West & 0.171055 & 0.177595 & 0.179618 & 0.180375 & 0.440531 & 0.461206 & 0.462878 & 0.446524 \\
\hline
\end{tabular}

Source: authors' own computations based on EUROSTAT data

The regions more specialised in the examined period (2000-2013) (Table 2a) are: North-West, South-West Oltenia and South-Muntenia. In other regions, such as: Centre, North-East, Bucharest-Ilfov and West specialisation decreased in the favor of diversification. The entropy indexes increased significantly in North-West, South-West Oltenia, and South-Muntenia. Small increases were registered in North-East, South-East and Bucharest- Ilfov regions.

Based on the values of Hirschman-Herfindahl index (Table 2b), we can notice that all regions became less specialised in the distribution of employed people between 
Regional specialisation and economic concentration in Romania

economic sectors. The highest differences are registered in North-East, SouthMuntenia and South-West Oltenia. The richest region (Bucharest-Ilfov) is very stable: it has small variations in the explored period of time. The values of Gini coefficients reflect a small distance to an equal distribution of employed people between economic sectors in the Romanian regions.

Table 2.a Specialisation of Romanian regions based on employment data

\begin{tabular}{|l|c|c|c|c|c|c|c|c|}
\cline { 2 - 9 } \multicolumn{1}{c|}{} & \multicolumn{4}{c|}{ Krugman Index } & \multicolumn{4}{c|}{ Entropy Index } \\
\hline Year/Region & $\mathbf{2 0 0 0}$ & $\mathbf{2 0 0 5}$ & $\mathbf{2 0 0 9}$ & $\mathbf{2 0 1 2}$ & $\mathbf{2 0 0 0}$ & $\mathbf{2 0 0 5}$ & $\mathbf{2 0 0 9}$ & $\mathbf{2 0 1 2}$ \\
\hline North-West & 0,0982551 & 0,1071693 & 0,0893883 & 0,7522788 & 0.680959 & 0.741537 & 0.774434 & 0.766321 \\
\hline Centre & 0,3735913 & 0,3193148 & 0,2931288 & 0,3617215 & 0.728043 & 0.754863 & 0.779877 & 0.788880 \\
\hline North-East & 0,417159 & 0,4108589 & 0,385608 & 0,3758559 & 0.521311 & 0.637597 & 0.683995 & 0.679431 \\
\hline South-East & 0,0605384 & 0,0688295 & 0,0728217 & 0,0655557 & 0.665304 & 0.741104 & 0.783098 & 0.754595 \\
\hline $\begin{array}{l}\text { South - } \\
\text { Muntenia }\end{array}$ & 0,1295497 & 0,1389756 & 0,1511457 & 0,1568906 & 0.626786 & 0.711863 & 0.738929 & 0.736963 \\
\hline $\begin{array}{l}\text { Bucharest - } \\
\text { Ilfov }\end{array}$ & 0,8907192 & 0,7596231 & 0,6993976 & 0,7591987 & 0.808573 & 0.848666 & 0.838982 & 0.850218 \\
\hline $\begin{array}{l}\text { South-West } \\
\text { Oltenia }\end{array}$ & 0,2999581 & 0,2996437 & 0,3696736 & 0,3750364 & 0.559948 & 0.662358 & 0.660630 & 0.660917 \\
\hline West & 0,3053821 & 0,2569623 & 0,2558348 & 0,2852709 & 0.728607 & 0.765828 & 0.764859 & 0.759266 \\
\hline
\end{tabular}

Source: authors' own computations based on EUROSTAT data

Table 2.b Specialisation of Romanian regions based on employment data

\begin{tabular}{|l|c|c|c|c|c|c|c|c|}
\cline { 2 - 9 } \multicolumn{1}{c|}{} & \multicolumn{4}{c}{ Hirschman-Herfindahl Index } & \multicolumn{4}{c|}{ Gini Coefficient } \\
\hline Year/Region & $\mathbf{2 0 0 0}$ & $\mathbf{2 0 0 5}$ & $\mathbf{2 0 0 9}$ & $\mathbf{2 0 1 2}$ & $\mathbf{2 0 0 0}$ & $\mathbf{2 0 0 5}$ & $\mathbf{2 0 0 9}$ & $\mathbf{2 0 1 2}$ \\
\hline North-West & 0.270853 & 0.222149 & 0.200258 & 0.206750 & 0.640028 & 0.578236 & 0.541277 & 0.552243 \\
\hline Centre & 0.233209 & 0.222496 & 0.201626 & 0.196789 & 0.595618 & 0.568299 & 0.540024 & 0.529873 \\
\hline North-East & 0.461273 & 0.335885 & 0.297007 & 0.297523 & 0.733992 & 0.665403 & 0.622535 & 0.624367 \\
\hline South-East & 0.290975 & 0.223967 & 0.194241 & 0.210931 & 0.651034 & 0.581355 & 0.528740 & 0.562201 \\
\hline South - Muntenia & 0.329155 & 0.250089 & 0.225345 & 0.231144 & 0.680253 & 0.612311 & 0.583981 & 0.586862 \\
\hline Bucharest - Ilfov & 0.184042 & 0.176121 & 0.180744 & 0.176778 & 0.516215 & 0.459498 & 0.470687 & 0.451039 \\
\hline $\begin{array}{l}\text { South-West } \\
\text { Oltenia }\end{array}$ & 0.405005 & 0.300913 & 0.300698 & 0.303919 & 0.719700 & 0.653718 & 0.652480 & 0.647467 \\
\hline West & 0.237283 & 0.218805 & 0.213041 & 0.216922 & 0.593931 & 0.559094 & 0.556812 & 0.563842 \\
\hline
\end{tabular}

Source: authors' own computations based on EUROSTAT data

The values of Krugman Index (Figure 1.a) reflect an increase of concentration for financial and insurance and real estate activities, agriculture, industry, wholesale and retail trade and a decrease for arts, entertainment and recreation, professional, scientific and technical activities, construction and public administration, in the examined period (2000-2013). The entropy indexes decreased in construction, information and communication sectors and increased in arts, entertainment and recreation, financial and insurance activities (Figure 1.b).

The Hirschman-Herfindahl Index (Figure 1.c) increased in construction, information and communication, financial and insurance sectors and decreased in real estate and arts, entertainment and recreation sectors. 
The activities became more concentrated in the following sectors according to the values of the Gini Coefficient: agriculture, industry, construction, information and communication, financial and insurance activities and more dispersed in real estate and arts sectors (Figure 1.d).

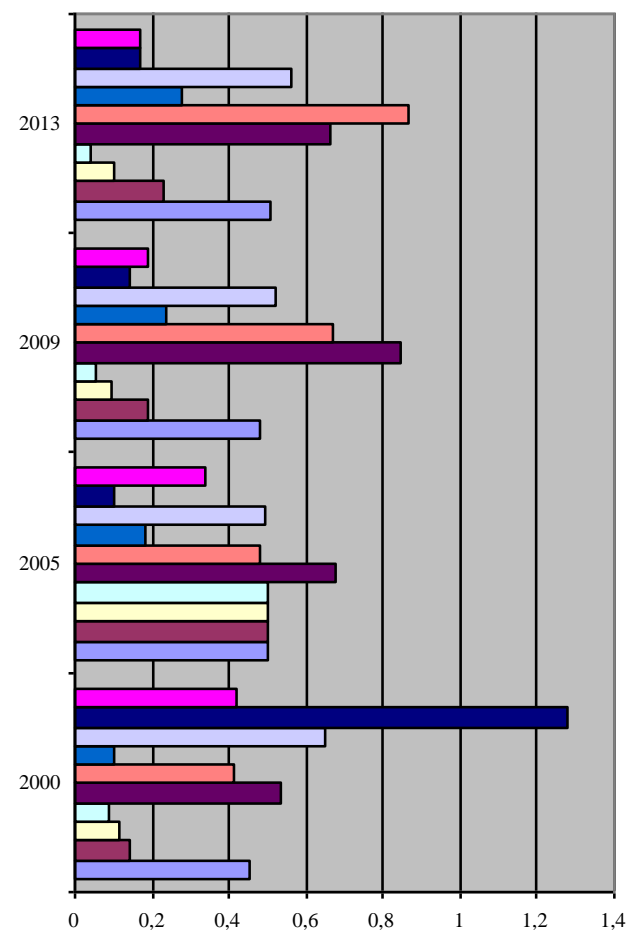

口 Arts, entertainment and recreation; other service activities; activities of

- Public administration, defence, education, hum an health and social work

- Professional, scientific and technical activities; administrative and suppo

$\square$ Real estate activities

$\square$ Financial and insurance activities

- Information and communication

$\square$ Wholesale and retail trade, transport, accomodation and food service ac

口 Construction

$\square$ Industry

$\square$ Agriculture, forestry and fishing

Figure 1.a Concentration of economic activities based on Gross Value Added data -Krugman Index

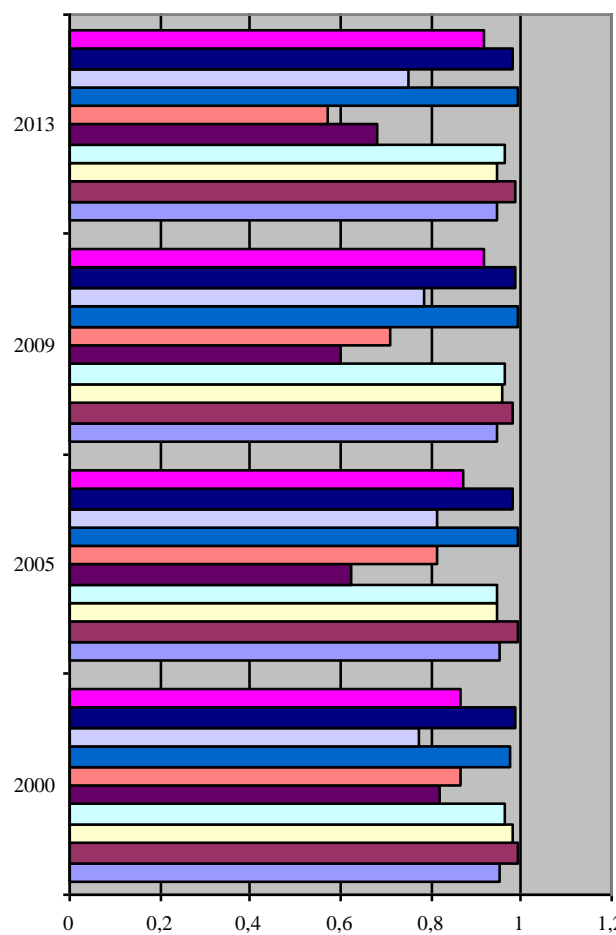

口 Arts, entertainment and recreation; other service activities; activities of $h$ - Public administration, defence, education, human health and social work $\square$ Professional, scientific and technical activities; administrative and suppor $\square$ Real estate activities

$\boldsymbol{\square}$ Financial and insurance activities

- Information and communication

$\square$ Wholesale and retail trade, transport, accomodation and food service act $\square$ Construction

$\square$ Industry

$\square$ Agriculture, forestry and fishing

Figure 1.b Concentration of economic activities based on Gross Value Added data -Entropy Index

Source: authors' own computations based on EUROSTAT data 
Neagu O., Neagu M.I. (2016)

Regional specialisation and economic concentration in Romania

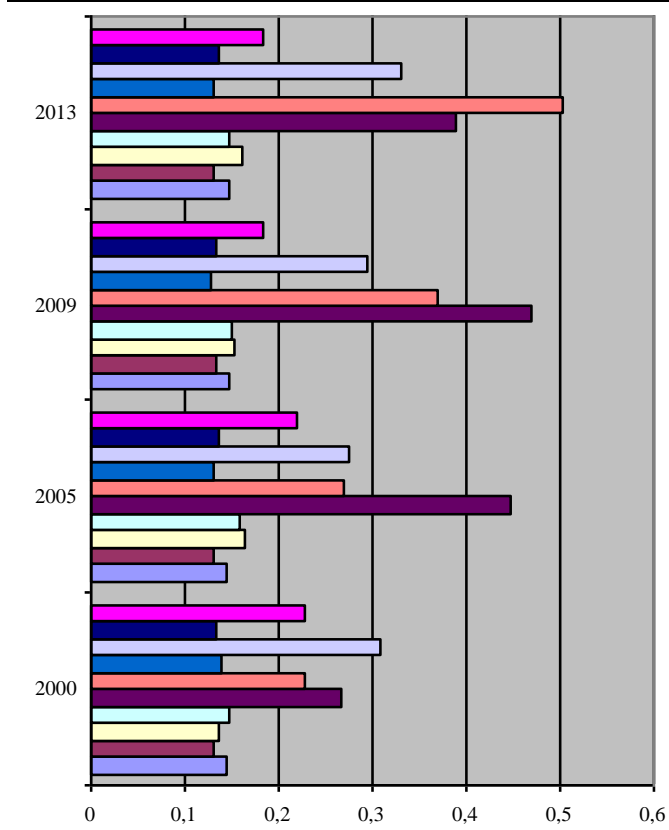

- Arts, entertainment and recreation; other service activities; activities of household and extra-territorial organizations and bodies

- Public administration, defence, education, human health and social work activities

$\square$ Professional, scientific and technical activities; administrative and support service activities

$\square$ Real estate activities

$\boldsymbol{\square}$ Financial and insurance activities

- Information and communication

$\square$ Wholesale and retail trade, transport, accomodation and food service activities

$\square$ Construction

Industry

$\square$ Agriculture, forestry and fishing

Figure 1.c Concentration of economic activities based on Gross Value Added data - Hirschman-Herfindahl Index

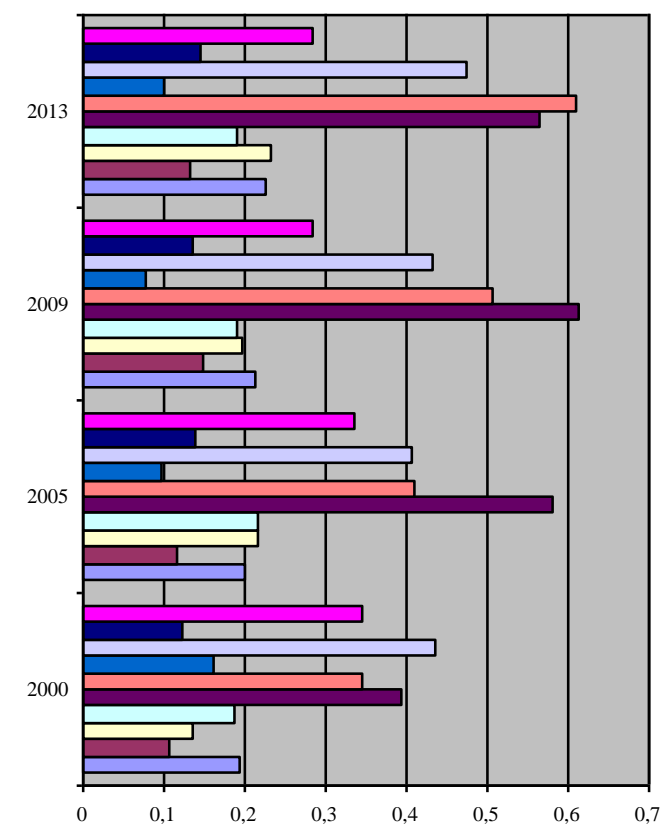

- Arts, entertainment and recreation; other service activities; activities of household and extra-territorial organizations and bodies

- Public administration, defence, education, hum an health and social work activities

口 Professional, scientific and technical activities; administrative and support service activities

- Professional, scientific and technical activities; administrative and support service activities

口 Financial and insurance activities

- Information and communication

Q Wholesale and retail trade, transport, accomodation and food service activities

$\mathbf{c}$ Construction

口 Industry

$\square$ Agriculture, forestry and fishing

Figure 1.d Concentration of economic activities based on Gross Value Added data -Gini Coefficient

Source: authors' own computations based on EUROSTAT data

According to the values Krugman Index (Table 2.a) the activities in agriculture, industry, information and communication became more concentrated in 2012 compared to 2000, while in sectors such as: construction, trade, financial activities and arts sectors they became less concentrated. The evolution of Entropy Indexes 
Neagu O., Neagu M.I. (2016)

Regional specialisation and economic concentration in Romania

shows an increase of economic concentration in all economic sectors in 2012 compared to 2000.

Table 2.a Concentration of economic activities based on employment data

\begin{tabular}{|c|c|c|c|c|c|c|c|c|}
\hline & \multicolumn{4}{|c|}{ Krugman Index } & \multicolumn{4}{|c|}{ Entropy Index } \\
\hline Year/Branch & 2000 & 2005 & 2009 & 2012 & 2000 & 2005 & 2009 & 2012 \\
\hline $\begin{array}{l}\text { Agriculture, forestry } \\
\text { and fishing }\end{array}$ & 0,3224234 & 0,3948022 & 0,4249043 & 0,4246433 & 0.877400 & 0.877430 & 0.878355 & 0.885988 \\
\hline Industry & 0,239108 & 0,2241136 & 0,2459807 & 0,2891019 & 0.990755 & 0.990239 & 0.990157 & 0.983333 \\
\hline Construction & 0,4985799 & 0,21937 & 0,1883207 & 0,1400975 & 0.981548 & 0.981504 & 0.977682 & 0.975745 \\
\hline $\begin{array}{l}\text { Wholesale and retail } \\
\text { trade, transport, } \\
\text { accommodation and } \\
\text { food service activities }\end{array}$ & 0,3177153 & 0,2461514 & 0,2270882 & 0,21684 & 0.984262 & 0.984315 & 0.983505 & 0.977598 \\
\hline $\begin{array}{l}\text { Information and } \\
\text { communication }\end{array}$ & 0,6283427 & 0,6600718 & 0,6002609 & 0,7426973 & 0.848821 & 0.849102 & 0.853722 & 0.783805 \\
\hline $\begin{array}{l}\text { Financial and } \\
\text { insurance activities }\end{array}$ & 0,6668413 & 0,4381072 & 0,5642429 & 0,5759049 & 0.931734 & 0.932039 & 0.945765 & 0.883217 \\
\hline Real estate activities & 0,5688626 & 0,6181858 & 0,5642429 & 0,5759049 & 0.890118 & 0.890897 & 0.853542 & 0.855706 \\
\hline $\begin{array}{l}\text { Professional, } \\
\text { scientific and } \\
\text { technical activities; } \\
\text { administrative and } \\
\text { support service } \\
\text { activities }\end{array}$ & 0,5330405 & 0,4743535 & 0,4259972 & 0,5152214 & 0.915081 & 0.916405 & 0.925775 & 0.885288 \\
\hline $\begin{array}{l}\text { Public } \\
\text { administration, } \\
\text { defence, education, } \\
\text { human health and } \\
\text { social work activities }\end{array}$ & 0,195059 & 0,1287117 & 0,13392 & 0,1747855 & 0.990590 & 0.990571 & 0.987225 & 0.983640 \\
\hline $\begin{array}{l}\text { Arts, entertainment } \\
\text { and recreation; other } \\
\text { service activities; } \\
\text { activities of } \\
\text { household and extra- } \\
\text { territorial } \\
\text { organizations and } \\
\text { bodies }\end{array}$ & 0,3437517 & 0,2710606 & 0,2259805 & 0,3082746 & 0.984979 & 0.984685 & 0.975504 & 0.971628 \\
\hline
\end{tabular}

Source: authors' own computations based on EUROSTAT data

According to the Hirschman-Herfindahl Index (Table 2b) the economic activities became in the last years more concentrated in industry, information and communication, financial insurance and real estate sectors and less concentrated in agriculture. The Gini coefficients highlight an increase of concentration in almost all economic branches, excepting agriculture.

We calculated the Lilien Index to emphasize the speed of sectoral reallocations of employment in the economy as the main factor of specialisation trend (Table 3). We notice that the speed was higher in the first period (2005 compared to 2000) in all regions, followed by a slowdown in the last years. The most dynamic region is Bucharest-Ilfov, followed by South-West Oltenia. These two regions are the only ones which after the crisis have had the potential to grow their speed of structural 
Neagu O., Neagu M.I. (2016)

Regional specialisation and economic concentration in Romania

changes. The region with the lowest structural speed, in the last years, (2012 compared to 2009) is West, followed by South-Muntenia and North-West.

Table 2.b Concentration of economic activities based on employment data

\begin{tabular}{|c|c|c|c|c|c|c|c|c|}
\hline & \multicolumn{4}{|c|}{ Hirschman-Herfindahl Index } & \multicolumn{4}{|c|}{ Gini Coefficient } \\
\hline Year/Branch & 2000 & 2005 & 2009 & 2012 & 2000 & 2005 & 2009 & 2012 \\
\hline $\begin{array}{l}\text { Agriculture, forestry } \\
\text { and fishing }\end{array}$ & 0.183558 & 0.183551 & 0.184183 & 0.178125 & 0.375646 & 0.375623 & 0.376836 & 0.365262 \\
\hline Industry & 0.129664 & 0.129929 & 0.129967 & 0.133199 & 0.109295 & 0.112416 & 0.112749 & 0.141053 \\
\hline Construction & 0.134420 & 0.134442 & 0.135832 & 0.137098 & 0.152594 & 0.152778 & 0.165999 & 0.175039 \\
\hline $\begin{array}{l}\text { Wholesale and retail } \\
\text { trade, transport, } \\
\text { accommodation and } \\
\text { food service activities }\end{array}$ & 0.133668 & 0.133632 & 0.133950 & 0.137586 & 0.131774 & 0.131502 & 0.135218 & 0.160280 \\
\hline $\begin{array}{l}\text { Information and } \\
\text { communication }\end{array}$ & 0.240578 & 0.240358 & 0.229876 & 0.292746 & 0.362794 & 0.362128 & 0.387490 & 0.462173 \\
\hline $\begin{array}{l}\text { Financial and } \\
\text { insurance activities }\end{array}$ & 0.169472 & 0.169213 & 0.159168 & 0.204826 & 0.270126 & 0.270005 & 0.242503 & 0.353393 \\
\hline Real estate activities & 0.199456 & 0.198879 & 0.221566 & 0.228961 & 0.347619 & 0.346239 & 0.411170 & 0.384073 \\
\hline $\begin{array}{l}\text { Professional, } \\
\text { scientific and } \\
\text { technical activities; } \\
\text { administrative and } \\
\text { support service } \\
\text { activities }\end{array}$ & 0.184413 & 0.183287 & 0.176274 & 0.207842 & 0.281094 & 0.279976 & 0.259731 & 0.324297 \\
\hline $\begin{array}{l}\text { Public } \\
\text { administration, } \\
\text { defence, education, } \\
\text { human health and } \\
\text { social work activities }\end{array}$ & 0.129841 & 0.129852 & 0.131623 & 0.133618 & 0.109407 & 0.109371 & 0.129463 & 0.139781 \\
\hline $\begin{array}{l}\text { Arts, entertainment } \\
\text { and recreation; other } \\
\text { service activities; } \\
\text { activities of } \\
\text { household and extra- } \\
\text { territorial } \\
\text { organizations and } \\
\text { bodies }\end{array}$ & 0.133440 & 0.133597 & 0.137506 & 0.141263 & 0.132654 & 0.134098 & 0.175565 & 0.186210 \\
\hline
\end{tabular}

Source: authors' own computations based on EUROSTAT data

Table. 3 Structural changes in Romania

\begin{tabular}{|c|c|c|c|}
\hline Region & $\mathbf{2 0 0 5 - 2 0 0 0}$ & $\mathbf{2 0 0 9 - 2 0 0 5}$ & $\mathbf{2 0 1 2 - 2 0 0 9}$ \\
\hline Romania & 0,207528437 & 0,14270039 & 0,0757929 \\
\hline North-West & 0,173528035 & 0,155384927 & 0,11583904 \\
\hline Centre & 0,212176001 & 0,176639873 & 0,14829587 \\
\hline North-East & 0,158883561 & 0,181316711 & 0,15229739 \\
\hline South-East & 0,228089622 & 0,194057799 & 0,12519704 \\
\hline South - Muntenia & 0,409891458 & 0,158084868 & 0,10151224 \\
\hline Bucharest - Ilfov & 0,297057193 & 0,156221636 & 0,31405958 \\
\hline South-West Oltenia & 0,337409907 & 0,119745642 & 0,21265607 \\
\hline West & 0,314883106 & 0,099951398 & 0,08568413 \\
\hline
\end{tabular}

Source: authors' own computations based on EUROSTAT data 
The main consequence of the employment reallocations is that regions became less specialised and economic branches more concentrated. This outcome is in line with the theories stating that specialisation and concentration are two facets of the same coin and can evolve together (Aiginger and Rossi-Hansberg, 2006).

\section{Discussion and conclusions}

The paper aimed to highlight the dynamics of specialisation and economic concentration in the Romanian regions in the period of 2000-2013. We have used several statistical indexes to reflect the economic evolution of these two phenomena.

Regarding the regional specialisation based on Gross Value Added we found that the regions of North-West and Centre (according to the values of Krugman Index) are the closest to the national economic structure, while Bucharest-Ilfov is the farthest to it. The differences between the regional and the national economic structure have been increasing in the last years. According to the HirschmanHerfindahl index, the southern regions became more specialised (South-East, South-Muntenia, South-West Oltenia and West), the North-East and BucharestIlfov regions have diversified their activities and North-West and Centre regions remained almost stable. The values of Gini coefficient indicate a different dynamics, as follows: the South-East region is the only one, more specialised in the examined period of time; other regions such as: North-West, Centre, North-East and Bucharest-Ilfov became more diversified and the Southern regions remained stable as economic structure. The economic entropy is decreasing in the Southern regions and increasing in Northern and Central Romania and in Bucharest-Ilfov.

The measurement of specialisation based on regional employment data and expressed by Hirschman-Herfindahl Index and Gini Coefficients suggests a trend of diversification in all regions. The economic entropy increased in all regions and the similarity between the regional and the national economic structure increased in Centre, North-East, West and Bucharest-Ilfov and decreased in Southern and North-Western regions.

Concerning the economic concentration measured by Gross Value Added of economic branches, we found different results, according to the statistical indicators used in the analysis. For instance, the values of Krugman Index reflect a lower similarity of concentration to the national trend for financial and insurance and real estate, agriculture, industry, wholesale and retail trade activities while the Hirschman-Herfindahl Index adds to these branches the sector of constructions. The values of Gini Coefficient indicate similar results with Hirschman-Herfindahl Index. 
The same measurements based on sectorial employment data show us that the economic branches which became more different as national economic structures are: agriculture, industry, information and communications. All other economic sectors are converging to the national economic structure. The entropy raised in all economic sectors. According to the Gini Coefficient, all branches became more concentrated, excepting agriculture. The Hirschman-Herfindahl Index indicates the highest increase of concentration in: information and communication, financial and insurance activities, real estate and professional activities sectors.

The speed of structural changes in all Romanian regions registered a noticeable slowdown of the speed of sectorial changes after the economic crisis (2012 compared to 2009).

Taking into consideration the above findings, we can conclude that the measurement of regional specialisation and economic concentration with different statistical indicators can offer a complete picture of the economic dynamics and structural changes at regional level. We identified a trend of a decreasing specialisation of regions and a slight increase of economic concentration in Romania in the last 15 years.

Our findings are in line with other empirical studies on Romanian regional economy (please see Goschin et al. 2008, 2009) and with the theory of RossiHansberg (2005), stating that specialisation and concentration can evolve in opposite directions.

Our conclusions provide useful information for the economic policy makers in investment funds allocation or employment measures designed within regional development strategies.

\section{References}

1. Andrei, T., Vlad, L.B., Nedelcu, M. (2008). Tendency in Regional Industry and Specialisation in Romania during the Transition Period. Theoretical and Applied Economics, Vol.3, pp. 3-12.

2. Andrei T., Mitrut, C. Constantin, D.L. (2009). Regional Specialisation and Industrial Concentration in Romania's Transition Period from an Election Cycle Perspective, Environment and Planning C Government and Policy, Vol. 27, No.4, pp.713-731.

3. Aiginger, K. (1999). Do industrial structures converge? A survey of on the empirical literature on specialization and concentration of industries. Retrieved from: http://www.wifo.ac.at/jart/prj3/wifo/resources/person_dokument/person_dokument.jart?pub likationsid $=8179 \&$ mime_type $=$ application/pdf Accessed: 14.03.2016.

4. Aiginger, K., Davies, St. (2004). Industrial specialization and geographic concentration: two sides of the same coin? Not for the European Union. Journal of Applied Economics, Vol.12, pp.231-248.

14 DE GRUYTER OPEN
Studia Universitatis "Vasile Goldis" Arad. Economics Series Vol 26 Issue 3/2016 ISSN: 1584-2339; (online) ISSN: 2285 - 3065

Web: publicatii.uvvg.ro/index.php/studiaeconomia.Pages $1-17$ 
5. Aiginger, K., Pfaffermayr, M. (2004). The Single Market and Geographic Concentration in Europe. Review of International Economics, Vol.12, pp.1-11.

6. Aiginger, K., Rossi-Hansberg, E. (2006). Specialization and concentration: a note on theory and evidence. Empirica, Vol.33, pp.255-266.

7. Attaran, M., Zwick, M. (1987). Entropy and Other Measures of Industrial Diversification. Quarterly Journal of Business and Economics, Vol.26, pp.17-35.

8. Beine, M., Coulombe, S. (2007). Economic integration and the diversification of regional exports: evidence from the Canadian-U.S: Free Trade Agreement.Journal of Economic Geography, Vol.7, pp.93-111.

9. Cornett, A. (2002). Regional Cohesion in an Enlarged European Union. In J.R. Cuadrado-Roura, M. Parellada (Eds), Regional Convergence in the European Union. Facts, Prospects and Policies, Springer-Verlag, Berlin.

10. Cowell, F.A. (1980). On the structure of additive inequality measures. Review of Economic Studies, Vol.47, pp.521-531.

11. Cowell, F.A. (1995). Measuring Income Inequality, 2nd Edition, Harvester Wheatsheaf, Hemel Hempstead.

12. Cowell, F.A. (2000). Measurement of inequality. In: Atkinson, A.B. and F. Burguignon (eds.) Handbook of Income Distribution, pp. 87-166, Amsterdam.

13. Dalum, B., Laursen, K., Villumsen (1998). Structural change in OECD Export Specialization Patterns: De-specialization and "Stickiness". International Review of Applied Economics, Vol. 12, No.3, pp.423-443

14. Davis, D.R. (1998). The Home Market.Trade, Trade and Industrial Structure. American Economic Review, Vol.88, pp.1264-1276.

15. Ezcurra, R., Pascual, P., Rapun. M. (2006). Regional Specialization in the European Union.Regional Studies, Vol. 40, No. 6, p. 601-616.

16. Goschin, Z., L., Roman, M., Ileanu, B. (2009). Regional specialization and geographic concentration of industries in Romania. Retrieved from at: http://www.asecu.gr/files/ RomaniaProceedings/27.pdf. Accesed 25.03.2016.

17. Goschin, Z., Constantin, D.L., Roman, M., Ileanu, B. (2008). The current state od dynamics of regional disparities in Romania. Romanian Journal of Regional Sciences, Vol.2. No.2, pp.81-105.

18. Hallet, M. (2002). Regional Specialization and Concentration in the EU. In J.R. Cuadrado-Roura, M. Parellada (Eds), Regional Convergence in the European Union. Facts, Prospects and Policies, Springer-Verlag, Berlin.

19. Herfindahl, O.C. (1950). Concentration in the Steel Industry, Ph.D thesis, Columbia University.

20. Hirschman, A.O. (1964). The Paternity of an Index. The American Economic Review, Vol. 54, pp.761-762

21. Krugman, P. (1991). Increasing returns and economic geography. Journal of Political Economy, Vol.99, pp.183-199.

22. Lilien, D.M. (1982). Sectorial Shifts and Cyclical Unemployment. Journal of Political Economy, no 90, p. 777-793.

Studia Universitatis "Vasile Goldis" Arad. Economics Series Vol 26 Issue 3/2016 ISSN: 1584-2339; (online) ISSN: 2285 - 3065

Web: publicatii.uvvg.ro/index.php/studiaeconomia.Pages $1-17$ 
23. Longhi, S., Nijkamp, P., Traistaru, I. (2004). Economic Integration and Regional Structural Change in a Wider Europe: Evidence from New and Accession Countries. Journal for Institutional Innovation Development and Transition, Volume 8, pp.48-55.

24. Marelli E. (2007). Specialization and Convergence of European Regions. The European Journal of Comparative Economics, no 2, p. 149-178.

25. Mitruț, C., Constantin, D.L. (2006). Current Issues Concerning Regional Policy and SMEs in Romania. South-Eastern Europe Journal of Economics, Vol. 4, No.2, Fall 2006, pp. 209-222.

26. Neagu, O. (2013). Measurement of territorial convergence. An analysis in the case of Romania. Annals of "Constantin Brâncusi" University of Tg.Jiu, Economic Series, Issue 3/2013, p. 117-125.

27. Neagu, O. (2015). The Regional Economic Convergence in Romania: an Analysis based on the Enthropy Approach. Ovidius University Annals of Economics, Vol XV, issue 1, 2015, p.189-194.

28. Rossi-Hansberg, E. (2005), "A spatial theory of trade", American Economic Review, 95(5), p. 1464-1491.

29. Simionescu, M. (2014). The convergence of employment rate in the European Union.Studia Universitatis "Vasile Goldis" Arad, Economic Series, Vol.24, Issue 3/2014, pp.62-69.

30. Sapir, A. (1996). The Effects of Europe's Internal Market Program on Production and Trade: A First Assessment. Weltwirtschaftliches Archiv, Vol.132, pp.457-475.

31. Scherer, F.M. (1990). Industrial market structure and economic performance, 3rd ed. Boston.

32. Smith, S.M., Gibson, C.M. (1988). Industrial Diversification in Nonmetropolitan Counties and Its Effect on Economic Stability. Western Journal of Agricultural Economics, Vol.13, pp.193-201.

33. Storper, M., Chen, Y., De Paolis, F. (2002). Trade and the location of industries in the OECD and European Union. Journal of Economic Geography, Vol.2, pp.73-107.

34. Traistaru, I. (1999). Regional patterns of private enterprise development in Romania. Working Paper, Center for European Integration Studies, University of Bonn. Retrieved from: http://www.econstor.eu/bitstream/10419/115251/1/ERSA2001_198.pdf. Accessed 21.03.2016.

35. Traistaru, I., Iara, A. (2002). European Integration, Regional Specialization, and Location of Industrial Activity in Accession Countries: Data and Measurement, Center for European Integration Studies, University of Bonn. Retrieved from: https://www. researchgate.net/profile/Iulia_Siedschlag/publication/265935731_European_Integration_Re gional_Specialization_and_Location_of_Industrial_Activity_in_Accession_Countries_Data _and_Measurement/links/54f58f410cf2ba6150668c50.pdf. Accessed 18.03.2016

36. Traistaru, I., Nijkamp, P., Longhi, S. (2002). Regional specialisation and location of industrial activity in accession countries. 42nd Congress of the European Regional Science Association, Dortmund, 27th-31st August 2002. Retrieved from: http://www.econstor. eu/bitstream/10419/115632/1/ERSA2002_136.pdf Accessed 29.03.2016.

16 DE GRUYTER OPEN
Studia Universitatis "Vasile Goldis" Arad. Economics Series Vol 26 Issue 3/2016

ISSN: 1584-2339; (online) ISSN: 2285 - 3065

Web: publicatii.uvvg.ro/index.php/studiaeconomia.Pages $1-17$ 
Neagu O., Neagu M.I. (2016)

Regional specialisation and economic concentration in Romania

37. Traistaru, I., Nujkamp, P., Resmini, L. (2003). The emerging Economic Geography in EU Accession Countries. Ashgate Publishing.

38. Tauer, L.W., (1992). Diversification of production activities across individual states. Journal of Production Agriculture, Vol.5, pp.210-214.

39. http://ec.europa.eu/eurostat/web/regions/statistics-illustrated

40. http://www.wessa.net/. 